DOI https://doi.org/10.30525/978-9934-26-040-7-12

\title{
СТАНОВЛЕННЯ ІНСТИТУТІВ БЕЗПОСЕРЕДНЬОЇ ДЕМОКРАТІЇ В УКРАЇНІ: МИНУЛЕ ТА СЬОГОДЕННЯ
}

\author{
Пачевська Г. М. \\ здобувач кафедри теорії держави та права \\ Національної академії внутрішніх справ \\ м. Київ, Україна
}

Верховенство права, демократія та права людини - тріада правових європейських цінностей демократичної держави, зокрема й України. У процесі таких державотворчих перетворень, як здобуття Україною незалежності в 1991 році та прийняття в 1996 році Конституції України, надало змогу нашій державі забезпечити реалізацію певних цілей та завдань, які окреслені в Основному Законі. Саме такий історичний вектор розвитку України, де права та свободи людини, їх гарантії визначають основний зміст та спрямованість діяльності держави, поставив перед вітчизняною юридичною наукою низку важливих теоретичних та практичних завдань у державотворчій та правотворчій сферах. Одним із таких завдань $\epsilon$ побудова демократичного суспільства. У зв'язку з цим поняття демократії, іiї принципи, форми, ознаки тощо стали об'єктом дослідження великої кагорти зарубіжних та вітчизняних дослідників, зокрема Л. Даймонда, Р. Даля, А. Лійпхарда, Е. Мак-Грю, Г. Світа, С.Головатого, С. Давимука, В. Забігайло, А. Заєць, А. Колодія, Ю. Кужелюка, В. Марченка, М.Оніщука, О. Петришина, П. Рабіновича, В. Селіванова та інших.

Про актуальність даного питання свідчить і те, що демократія $\epsilon$ об'єктом зацікавленості не лише 3 боку юридичних наук, а й соціальних, таких як філософія, політологія, економічна теорія тощо.

Для кращого розуміння сутності філософських засад демократії необхідно простежити її розвиток в історичній площині. Саме поняття «демократія» має давнє коріння, яке зазнавало трансформації в різні історичні періоди. Перші зародки примітивних форм демократії вважають первіснообщинну та військову, що грунтувались на кровноспоріднених зв'язках; малочисельності населення, низькій продуктивності праці та колективному володінні землею. Однак створення найпершої демократії приписують саме стародавнім грекам, а першою класичною формою демократичної держави вважають саме Афінську республіку (5 ст. до н.е). Хоча в часи стародавньої Греції демократія не 
знайшла підтримки серед більшості тогочасних філософів, однак іiі трактування та розуміння відрізнялось серед мислителів. Зокрема, давньогрецький філософ Арістотель схилявся до такої ж думки, як i Платон, та вважав, що демократія це неправильна форма правління та протиставляв iï політії (конституційне правління), що грунтується на правлінні більшості, однак відібрана на основі цензу та заради загального блага [1].

На нашу думку, таке ставлення до демократії $є$ наслідком того, що у Стародавній Греції поняття «демос» розуміли неоднаково, а саме «Темосом» називали і спільноту зібрану в народні збори, і народ у цілому й навіть чернь. [1, с. 224].

Доцільним буде закцентувати увагу на тому, що тогочасне розуміння демократії істотно відрізняється від сучасного. Головними відмінностями $є$ форма вияву демократії та коло осіб, які безпосередньо брали участь в обговореннях (тобто учасники обговорення). На відміну від сьогодення, в Афінській державі існували лише зародки прямої демократії - народ не обирав представників, які діятимуть та прийматимуть владні рішення від імені народу, а самостійно збирався на народні збори, обговорював питання уряду, а згодом реалізовував узгоджену політику, а коло учасників, які безпосередньо могли брати участь у таких обговореннях було дуже вузьким (діти, жінки, раби, іноземці не входили в це коло осіб). Вважаємо, що така модель афінської демократії була надто обмеженою та не забезпечувала захист прав меншості або інакомислення.

Згодом ідею народовладдя було доповнено християнськими цінностями, республіканськими ідеалами Н. Макіавеллі, концепціями державного (Ж. Боден) та народного (Ж.-Ж. Руссо) суверенітету, механізмом поділу влади Ш. Монтеск'є.

3 плином часу ідея народовладдя зазнавала деяких змін, а остаточну зміну світосприйняття на користь демократії пов'язують із Новим часом - добою буржуазних революцій в Англії та на європейському континенті, становленням США у формі демократичної республіки як «влади законів, а не людей». Петришин О. у своїй праці «Влада народу - народовладдя: основа демократичної держави» вважає, що не менш вагомим у поступі демократії $\epsilon$ й те, що засновники США зосередили увагу на конкретному дослідженні таких ключових інститутів демократії, як вибори, поділ влади, механізм «стримувань i противаг», статус законодавчої влади, незалежність судової влади $[4$, c. $58-59]$.

Якщо говорити про розвиток перших форм безпосередньої демократії на теренах України, то до них можна віднести віча, учасники яких не були обраними представниками. Як зазначає М.С. 
Грушевський «представництво не припускалося: кожний брав участь сам за себе» [2, с. 311]. До елементів тогочасних форм демократичного врядування можна віднести право обрання князя, укладення між ним i громадою публічного договору тощо. Водночас вважаємо, що у зв'язку 3 тогочасними політико-правовими та соціально-економічними відносинами було б перебільшенням говорити про такі основоположні засади демократії як народовладдя, права і свободи людини. Надалі демократичні традиції знайшли своє відображення в козацькогетьманською добу. Обгрунтування тогочасних принципів народовладдя та демократії були закріплені в Конституції П.Орлика, що стала своєрідним зразком оформлення демократичних відносин між народом та правителем.

Слід зазначити, що важливу роль у розвитку демократичної думки відіграло Кирило-Мефодіївське братство (основу якої склали ідеї народного месіанства і демократизму), а надалі визначальне місце слід відвести працям В. Антоновича, М. Драгоманова, С. Подолинського, які вважали основоположними ідеї конституціоналізму і політичної свободи у поєднанні із свободою особистості й повагою.

Важливим кроком у формуванні правової та демократичної держави в Україні став перехід від тоталітарних пережитків до суспільної, індивідуальної свободи. Адже, у порівнянні з радянським часом, де в основному панувала представницька демократія, проголошення незалежності України змінило пріоритет на користь безпосереднього здійснення народом належної йому державної влади, тобто прямого народовиявлення. Саме тому в чинній Конституції України задекларовано, що Україна є суверенна, незалежна, демократична, соціальна та правова держава [3], а народ визнаний носієм сувернітету та єдиним джерелом влади в державі, який здійснює владу безпосередньо і через органи державної влади та органи місцевого самоврядування. Зауважимо, що права та свободи людини, які закріплені в Конституції України свідчать про високий рівень розвитку демократії в Україні. Однак зазначимо, що зазначені постулати й досі потребують належної уваги з боку фахівців 3 метою їх належного виконання. Адже незважаючи на значні кроки, які здійснені щодо демократизації суспільства за роки незалежності, все ж залишаються питання, які потребують як теоретико-методологічного обгрунтування, так і законодавчого врегулювання. Зокрема, досить тривалий час було відсутнє нормативне регулювання щодо реалізації безпосередньої демократії шляхом референдуму і лише нещодавно Верховна Рада ухвалила новий закон про референдум. Однак вважаємо, що перегляду потребує й 3 розділ Конституції України, який $є$ надто узагальненим та лише в загальних рисах називає форми безпосередньої демократії, а тому як наслідок 
потребує суттєвого доопрацювання 3 метою повного висвітлення та врегулювання на законодавчому рівні.

Отже, можна зробити висновок, що не всі конституційні положення відображають реальне сучасне становище держави та суспільства, а деякі з них є стратегічними завданнями, які стають перед країною задля формування повної та всебічної демократії, та які спрямовують вектор розвитку держави у процесі подальших державотворчих перетворень 3 метою відповідності сучасному стану цивілізації та реалізації тих цілей державного та суспільного розвитку, які закріплені в Конституції України 1996 року.

\title{
Література:
}

1. Аристотель. Политика. Собрание соч. в 4 т. Т 4. Москва: Мисль, 1984. C. 37-644.

2. Грушевський М.С. Нарис історії Київської землі від смерті Ярослава до кінця 14 сторіччя. Київ, 1991. 560 с.

3. Конституція України: Закон України від 28 червня 1996 р. № 254к/96-ВР/Верховна Рада України. Відомості Верховної Ради України. 1996. № 30. Ст. 141.

4. Петришин О. В. Влада народу - народовладдя: основа демократичної держави . Право України. 2009. № 11. С. 58-65.

DOI https://doi.org/10.30525/978-9934-26-040-7-13

\section{МІСЦЕ СУДОВОГО ПРЕЦЕДЕНТУ У СИСТЕМІ ДЖЕРЕЛ УКРАЇНСЬКОГО ПРАВА}

\author{
Туз A-М. B. \\ студентка II курсу \\ Інституту права
}

Київського начіонального університету імені Тараса Шевченка м. Київ, Україна

В англо-саксонській правовій сім'ї судовий прецедент - це рішення судів загальної юрисдикції по конкретній справі, яке є обов'язковими для нижчестоящих та рівних за рангом судів при вирішенні аналогічної справи. Судові прецеденти відіграють важливу роль у правовому регулюванні, оскільки завдяки їм конкретизуються закони, 